\title{
FAKTOR YANG MEMPENGARUHI KEJADIAN ISPA PADA BALITA DI WILAYAH KERJA PUSKESMAS PASIR PUTIH KABUPATEN MUNA TAHUN 2018
}

\author{
Wa Deli ${ }^{1}$ Asnia Zainuddin ${ }^{2}$ Hilda Harun ${ }^{3}$ \\ 1,2,3Fakultas Kesehatan Masyarakat Universitas Halu Oleo \\ ${ }^{1}$ wadelifkm@gmail.com²asniaz@gmail.com 3hildamm2011@gmail.com
}

\begin{abstract}
Abstrak
Infeksi saluran pernapasan akut (ISPA) adalah infeksi saluran pernapasan atas dan bawah. Hal ini dapat diakibatkan oleh beberapa faktor seperti pola asuh orang tua, lingkungan rumah dan kondisi fisik rumah. Tujuan penelitian ini adalah untuk mengetahui faktor yang mempengaruhi kejadian ISPA pada balita di wilayah kerja Puskesmas Pasir Putih Kabupaten Muna Tahun 2018. Informan pada penelitian ini yaitu tiga orang ibu balita yang menderita ISPA sebagai informan kunci dan dua orang suami ibu balita yang bersedia menjadi informan biasa. Metode penelitian yang digunakan yaitu kualitatif dengan pendekatan studi kasus. Penentuan informan dengan menggunakan teknik purposive sampling dengan menetapkan ciri-ciri khusus yang sesuai dengan tujuan penelitian. Data diperoleh dengan melakukan telaah pustaka dan wawancara mendalam kepada semua informan. Dari hasil penelitian dapat disimpulkan bahwa kejadin ISPA pada balita terjadi karena ketidakpedulian dan kurangnya pemahaman ibu balita mengenai pola asuh yang baik, lingkungan rumah yang tercemar dan kondisi fisik rumah yang tidak memenuhi syarat kesehatan.
\end{abstract}

Kata kunci: ISPA, Fakto-faktor, Balita

\begin{abstract}
Acute respiratory infections (ARI) are upper and lower respiratory tract infections. This can be caused by several factors such as parenting, home environment and physical condition of the house. The stuady aimed to determine the factors that influence the incidence of ARI in children under five in the work area of Pasir Putih Health Center in Muna Regency in 2018. Informants in this study were three mothers of children under five suffering from ARI as key informants and two mother's' husband of children under five who were willing to become informants normal. The study method used was a qualitative with a case study approach. Determination of informants by using purposive sampling technique by specifying specific characteristics that were suitable with the objectives of the study. Data was obtained by conducting literature review and in-depth interviews with all informants. Based on the results of the study, it can be concluded that ARI in children under five was due to ignorance and lack of understanding of mothers of children under five about good parenting, polluted home environment and physical condition of houses that did not meet health requirements.
\end{abstract}

Keywords: ARI, Factors, Children Under Five 


\section{PENDAHULUAN}

ISPA merupakan penyebab utama kematian balita di dunia. Penyakit ini menyumbang $16 \%$ dari seluruh kematian anak di bawah 5 tahun, yang menyebabkan kematian pada 920,136 balita, atau lebih dari 2.500 per hari, atau diperkirakan 2 anak balita meninggal setiap menit pada tahun $2015^{1}$

ISPA merupakan salah satu penyebab utama konsultasi atau rawat inap di fasilitas pelayanan kesehatan terutama pada bagian perawatan anak. Sebesar $78 \%$ balita yang berkunjung ke pelayanan kesehatan adalah akibat ISPA. Kematian balita akibat ISPA di Asia Tenggara sebanyak 2.1 juta balita dan pada anak-anak dibawah 5 tahun insidensi ISPA sekitar 3-5 episode per anak/tahun. India, Bangladesh, Indonesia, dan Myanmar merupakan negara dengan kasus kematian balita akibat ISPA terbanyak $^{2}$

Kejadian Infeksi Saluran Pernapasan Akut didasarkan adanya interaksi antara komponen host, agen dan environment. Berubahnya satu komponen mengakibatkan keseimbangan terganggu sehingga menimbulkan penyakit ISPA. Faktor resiko kejadian ISPA pada balita dipengaruhi oleh faktor intrinsik (umur, jenis kelamin, status gizi, status imunisasi) dan faktor ekstrinsik meliputi kepadatan hunian tempat tinggal, polusi udara, ventilasi, letak dapur, jenis bahan bakar, penggunaan obat nyamuk, asap rokok, penghasilan keluarga, serta faktor pendidikan ibu, umur dan pengetahuan ibu ${ }^{3}$.

Dampak dari terganggunya sistem pernapasan yang merupakan salah satu gejala dari penyakit ISPA ini tidak baik bagi kesehatan, karena akan mengganggu sistem tubuh lainnya. Sulit bernapas membuat tubuh kekurangan oksigen yang sangat dibutuhkan tubuh. Akibatnya organ-organ tubuh lain tidak berfungsi dengan baik juga. ISPA juga menyebabkan sakit tenggorokan dan radang, karena virus masuk ke tenggorokan. Akibatnya sulit menelan makanan dan minuman. Batuk dan pilek yang biasanya datang bersamaan dengan sakit tenggorokan ini juga membuat tidak nafsu makan, sehingga tubuh pun menjadi lemas ${ }^{4}$.

Jumlah kasus Ispa pada balita menurut provinsi dan kelompok umur 1-4 tahun 2018, di indonesia terdapat 289,584 kasus. Sedangkan untuk provinsi Sulawesi Tenggara sendiri terdapat 1.563 kasus Ispa ${ }^{5}$.

Berdasarkan data dari Dinas Kesehatan Provinsi Sulawesi Tenggara pada tahun 2017 ISPA menempati urutan pertama dari 10 besar penyakit tertinggi di Sulawesi Tenggara dengan jumlah kasus sebanyak 28,720.
Berdasarkan data Dinas Kesehatan Kabupaten Muna pada tahun 2013 jumlah penderita ISPA pada balita sebanyak 611 kasus. Sedangkan pada tahun 2014 sebanyak 522 kasus dan tahun 2015 penderita ISPA pada balita tercatat sebanyak 328 kasus

Survei awal dari Puskesmas Pasir Putih bulan Januari-Oktober 2017 terdapat 151 balita yang terkena ISPA. Kasus ISPA di Puskesmas Pasir Putih pada tahun 2018 meningkat menjadi 188. Berdasarkan data yang diperoleh dari buku register Puskesmas Pasir Putih diperoleh data yang menunjukan bahwa penyakit ISPA setiap tahunya masuk dalam 10 besar penyakit yang sering muncul di wilayah kerja Puskesmas Pasir Putih.

Berdasarkan observasi pada 10 rumah balita ISPA pada tanggal 1-2 Januari 2019 terdapat 7 rumah dengan luas ventilasi kamar tidur balita tidak memenuhi syarat dan 6 rumah dengan jenis lantai tidak memenuhi syarat. Terdapat 8 rumah balita yang menggunakan kayu sebagai bahan bakar memasak dan itu sudah berlangsung selama 10 tahun. Dari faktor perilaku atau pengetahuan tentang pencegahan dan penanggulangan ISPA terdapat 7 rumah dengan perilaku penghuni yang tidak menerapkan etika batuk secara baik (tidak menutup mulut saat batuk) dan terdapat anggota keluarga yang merokok dalam rumah, serta ada 6 rumah dimana pengelolaan sampah masih dibakar di sekitar pekarangan rumah.

Tingginya angka kejadian ISPA merupakan salah satu masalah yang perlu mendapatkan perhatian. Berdasarkan uraian diatas maka peneliti tertarik melakukan penelitian dengan judul Faktor Yang Mempengaruhi Kejadian Ispa Pada Balita Di Wilayah Kerja Puskesmas Pasir Putih Kabupaten Muna Tahun 2018.

\section{METODE}

Pendekatan dan jenis penelitian ini adalah penelitian kualitatif dengan metode studi kasus (case study). Bertujuan untuk mengetahui data/fakta mengenai kejadian ISPA pada balita di wilayah kerja puskesmas Pasir Putih Kabupaten Muna.

Penentuan informan pada penelitian ini dilakukan dengan teknik purposive sampling , dimana peneliti menentukan pemilihan informan dengan menetapkan cicri-ciri khusus yang sesuai dengan tujuan penelitian sehingga diharapkan dapat menjawab permasalahan penelitian. sumber data utama dalam penelitian kualitatif adalah kata-kata dan tindakan, selebihnya adalah data tambahan seperti dokumen dan lainnya. Pada penelitian ini 
teknik pengumulan data menggunakan metode wawancara mendalam, observasi langsung di lapangan dan studi pustaka dan dokumentasi.

Penelitian ini dilaksanakan pada tanggal 22 Februari sampai selesai di Puskesmas Pasir Putih Kabupaten Muna. Penelitian ini dimaksukan untuk mencari informan secara mendalam mengenai kesiapan akreditasi Puskesmas Kandai berdasarakan Pokja UKM dalam memenuhi standar pelaksanaan akreditasi Puskesmas sebagai tuntutan akreditasi. Pelaksanaan penelitian dilakukan dengan mengumpulkan data primer dengan mewawancarai langsung Informan kunci (Kepala Puskesmas dan Penanggung jawab UKM) dan informan biasa (Pelaksana UKM dan Pasien) menggunakan panduan pedoman wawancara dengan instrumen HP sebagai alat perekam.

Berdasarakan variabel yang ada pada penelitian ini maka wawancara diarahkan kedalam tiga fokus penelitian, yaitu pola asuh orang tua, lingkungan fisik rumah, dak kondisi fisik rumah. Untuk lebih memahami pembahasan hasil penelitian akan diuraikan sebagai berikut :

\subsubsection{Pola Asuh Orang Tua}

Pola asuh orang tua mengenai pemberian makan berupa asupan energi dan protein pada balita kurang di perhatikan karena kesibukan dan ketidak pedulian terhadap pemberian makanan yang di berikan. Hal ini di jelaskan oleh informan kunci YT seperti pada kutipan wawancara berikut:

"anak saya ini hanya makan nasi yang di kasi hancur pakai air sayur kelor, anak saya tidak suka makan ikan atau telur. Jadi kalau dia makan kada saya campurkan dengan pilus garuda yang saya beli di warung itu dia suka kalau dia makan. Apa lagi kalau saya sudah pergi berkebun saya hanya suruhkan kakanya yang kasi makan. Mungkin karna dia tidak suka makan ikan jadi anak saya ini lemas sekali."

Pernyataan tersebut didukung oleh informan biasa LN, seperti pada kutipan wawancara berikut :

" kalau istri saya pergi di kebun anak saya ini hanya di kasi makan nasi yang di kasi hancur pakai air minum, istri saya hanya gorengkan kerupuk jadi di kasi dengan kerupuknya."

Untuk pencegahan dari penyakit ISPA, informan memberikan jawaban yang bervariasi namun secara garis besar informan masih belum memahami mengenai pencegahan dari penyakit. Hal ini dijelaskan oleh informan kunci $\mathrm{HI}$ seperti pada kutipan wawancara berikut:

"pencegahan dari kuman atau bakteri itu saya tidak terlalu perhatikan karna saya sibuk dengan pekerjaan saya berkebun jadi anak saya di rumah bermain saja karena ada kakaknya yang jaga, kadang di bermain di rumah tetangga sana baru di sini banyak sekali debu di halaman rumah ini jadi kalau saya pulang baju anak saya itu kotor sekali dia bermain tanah sama anaknya tetangga sana."

Pernyataan tersebut di dukung oleh informan biasa seperti pada kutipan wawancara berikut:

"istri saya tidak terlalu memperhatikan itu anak saya karena dia sibuk dengan pekerjaannya jadi kalau kita naik di kebuan anak saya di simpan sama kakaknya, kalau kita pulang itu baju anak saya kotor penuh dengan tanah. Istri saya sibuk, kecuali anak saya sudah tidak enak badan baru istri saya tidak naik di kebun dia urus mi anak saya itu."

Untuk pengobatan dini saat balita ISPA informan kurang mengetahui pengobatan saat balita ISPA. Hal ini dijelaskan oleh informan kunci SN seperti pada kutipan wawancara berikut:

"bagaimana saya bisa tahu cara pencegahanya penyakit ISPA ini kasian dek, saya ini hanya seorang petani kerjanya hanya di kebun, jadi mungkin saya tidak pernah mendengan bagaimana caranya mencegah penyakit ISPA itu. Petugas kesehatan juga jarang datang di rumah karena mungkin usat pelayanan kesehatan yang cukup jauh dengan rumah saya, saya juga jarang membawa anak saya ke posyandu dek. Palingan kalau di batuk dan panas saya bawa di dukun kadang di urut saya juga kompres pake kain saja kalau dia panas."

Pernyataan tersebut di dukung oleh informan biasa ND, seperti pada kutipan wawancara berikut:

"saya tidak mengetahui bagaimana penceegahannya itu, tapi kalau anak saya flu atau batuk kadang juga di sertai dengan badannya yang panas istri saya hanya pergi bawa anak saya di tukang urut dengan saya liat di kompres kepalannya pake air dinggin."

Berdasarkan wawancara tersebut dapat di ketahui bahwa pola asuh orang tua dalam hal ini pola asuh pemberian makanan berupa protein dan energi masih kurang di perhatikan karena kesibukan orang tua dan ketidakpedulian terhadap pemberian makanan pada balita. Selain itu pencegahan dan pengobatan saat balita ISPA belum di pahami oleh ibu balita.

\subsubsection{Lingkungan Rumah}

Mengenai cara mengolah sampah yang baik, kebanyakan informan memberikan jawaban yang hampir sama. Dimana informan mengolah sampah dengan cara di bakar di pekarangan rumah yang dapat menghasilkan asap, dimana asap dari hasil pembakaran sampah tersebut ketika di tiup angin mengarah di atas rumah. Dan pada saat pembakaran sampah itu balitanya ada di sekitaran pekarangan 
rumah. Hal ini dijelaskan oleh informan kunci SN seperti pada kutipan wawancara sebagai berikut:

"kalau di sini dek sampah itu selalunya kita bakar di samping rumah atau di belakang rumah, kecuali kalau sampah yang basah kita langsung buang saja di laut kebetulan d belakang rumah kita ini laut. Kalau untuk asap dari pembakaran sampah itu selalunya mengarah di atas rumah juga apa lagi kalau di tiup angin. Kadang juga saya bakar sampah ada balita saya yang di gendong sama kakaknya mereka bermain-main di sekitaran pekarangan rumah itu."

Pernyataan tersebut didukung oleh informan biasa ND dalam kutipan wawancara berikut:

"kalau istri saya dek sampah seperti daun-daun dan plastik botol itu selalunya di bakar di samping rumah atau di belakang rumah, yah mau bagaimana lagi dek di sini tidak ada tempat pembuangan sampah yang di sediakan jadi kita musnahkan dengan cara di bakar atau tidak di buang dia laut. Asapnya itu sebagian naik di atas rumah apa lagi kalau sudah di tiup angin asapnya lari di atas rumah baru anak saya masih sementara tidur atau bermain di atas rumah dengan kakaknya".

untuk indikator bahan bakar memasak informan masih menggunakan kayu bakar yang menghasilkan asap sebagai bahan memasak sehari-hari dan di dapur tidak ada cerbong asap. Hal ini dijelaskan informan kunci $\mathrm{HI}$ seperti pada kutipan wawancara sebagai berikut:

"saya kalau memasak dek menggunakan kayu bakar yang di ambil suami saya di hutan, tapi kalau lagi musim hujan kadang saya memasak pakai kompor minyak tanah. Kalau untuk memasak seharihari hanya kayu bakar yang kita pake dik, di dapur saya tidak ada cerbong asap semuanya kita tutup karna dia keras angin jadi kita tutup saja dengan karung atau kulit semen. Saya memasak biasa juga dengan balita saya di dapur kalau tidak ada yang jaga, kecuali dia sudah tidur baru saya memasak tidak gendong anak saya dek."

Pernyataan tersebut didukung oleh informan biasa LN dalam kutipan wawancara berikut:

"di sini dek sebagian besar penghasilan kita hanya berkebun, jadi kalau untuk bahan bakar memasak kita masih menggunakan kayu bakar, daripada uang kita belikan minyak tanah lebih baik kita belikan saja beras. Palingan kalau beli minyak tanah hanya untuk lampu tembok karna lampu di kampung sini belum normal dik, selalunya padam. Tidak ada tempat keluarnya asap di dapur, istri saya suruh tutup pakai seng atau kulit semen sengaja di tutup karna kerasa angin. Istri saya kalau dia memasak biasa ada anak saya di dapur karna tidak ada yang jaga apalagi kalau saya pergi kerja atau naik di kebun beru kakanya masih di sekolah jadi tidak ada yang jaga."

Untuk indikator paparan penghasil polutan informan memberikan jawaban yang sama di mana rumah mereka terdapat di pinggir jalan raya yang berdebu. Hal ini dijelaskan oleh informan kunci YT seperti pada kutipan wawancara sebagai berikut:

"kalau untuk penghasil polutan seperti tambang di sini tidak ada dek. Hanya saja rumah saya ini dekat dengan jalan raya, karena jalan tidak di aspal jadi berdebu, baru selalu debunya masuk dalam rumah kalau kita tidak tutup pintu, apa lagi kalau lewat mobil banyak sekali debu di jalan dek, kalau saya sendiri yang jaga anak saya ketika lewat kendaraan dan kemudian ada debu saya tutup hidungnya, tapi kalau tidak ada saya hanya di jaga sama kakaknya dia bermain tidak di hiraukan ada debu itu, namanya juga anak-anak mereka masih belum tau apa-apa."

Berdasarkan wawancara tersebut dapat diketahui bahwa terdapat pencemaran udara dilingkunan rumah maupun di dalam rumah informan seperti asap yang dihasilkan dari pembakaran sampah dan penggunaan kayu sebagai bahan bakar memasak serta paparan debu dari jalan raya.

\subsubsection{Kondisi Fisik Rumah}

Kondisi fisik rumah dalam hal ini jenis lantai, luas ventilasi dan masih belum memenuhi syarat rumah sehat, sedangkan untuk kepadatan hunian rumah informan sudah memenuhi syarat kesehatan. Hal ini dijelaskan oleh informan kunci SN, seperti pada kutipan wawancara sebagai berikut:

"untuk jumlah orang yang tinggal didalm rumah ini ada empat orang dek, dengan jumlah ruang tidur hanya dua kamar yang ruanganya tidak terlalu luas hanya muatan kasur dan lemari pakaian saja dek, kalau ada keluarga atau tamu yang datang ada juga ruangan di tengah sebagai tempat istrahat. iya kita tidur saja ber tiga dengan istri dan balita saya itu. Kalau soal sesak alhamdulillah kami bertiga bisa cukup tidur di dalam kamar tidur itu."

Untuk indikator luas ventilasi rumah informan belum memenuhi syarat kesehatan. Hal ini dijelaskan informan kunci $\mathrm{HI}$ seperti pada kutipan wawancara sebagai berikut:

"untuk luas ventilasi rumah saya tidak tahu berapa luasnya dek, karena di dalam rumah ini angin masuk ketika kita membuka pintu saja, saya tidak terlalu pusingkan harus ada ventilasi atau tidak yang penting di dalam rumah bisa untuk tidur dan melakukan pekerjaan lain. Mau bagaimana lagi dan dik biar juga ada keinginan untuk buat rumah yang memenuhi syarat kesehatan itu tapi lagi-lagi kita ini 
di kampung terkendala dengan biaya, mu kasih bagus meh juga rumah untuk makan sehari-hari saja kami cukup-cukupkan saja sesuai dengan penghasilan suami saya."

Pernyataan tersebut di dukung oleh informan biasa yang dikutip dalam wawancara sebagai berikut:

"Iuas ventilasi rumah menurut saya dek tidak terlalu lebar dan tidak terlalu sempit yang penting bisa keluar masuk angin, tapi kalau di rumah saya ini hanya jendela dan pintu tempat keluar masuknya angin, maklum saja dik rumah saya ini bukan permanen, jadi di sini yang memakai ventilasi itu hanya rumah-rumah permanen yang punya dinding beton atau tembok. Lagian dek biar tidak ada ventilasinya rumah tidak apa-apa yang penting bisa untuk tidur anak dan istri saya. Rumah saya masih seperti ini dek, jangankan mau perbaiki atau mau buat juga rumah seperti orang lain sana, penghasilan saya saja hanya bisa cukup untuk biaya makan dalam sebulan."

Untuk indikator jenis lantai rumah informan masih menggunakan lantai yang berbahan dasar tanah dan semen dan belum memenuhi syarat rumah sehat.. Hal ini dijelaskan oleh informan kunci $\mathrm{HI}$ yang dikutip dalam wawancara sebagai berikut:

"jenis lantai rumahnya kita ini dek masih menggunakan lantai tanah yang dilapis dengan tikar seadanya, kita belum punya uang untuk membuat lantai dari semen atau tehel itu. Jangankan mau bikin lantai pakai semen atau tehel dik, kalau ada uang kita masih gunakan untuk keperluan lain seperti beli beras, ikan dan bahan memasak di dapur."

Pernyataan tersebut didukung oleh informan biasa yang di kutip dalam wawancara sebagai berikut:

"jenis lantai rumah ini masih memakai dasar tanah hanya saja kita belikan tikar untuk pelapisnya supaya tidak kelihatan kotor atau berdebu, itu juga hanya di ruangan depan sama di ruangan kamar tidur, kalau di dapur tidak pakai tikar karna di sana hanya tempat memasak saja di dapur kita masih pakai sendal. Belum bisa di perbaiki ini lantai rumahnya kita ini karena belum juga ada biaya untuk menggantinya."

Berdasarkan wawancara tersebut dapat diketahui bahwa kondisi fisik rumah dalam hal ini luas ventilasi, jenis lantai belum memenuhi syarat rumah sehat akan tetapi untuk kepadatan hunian rumah informan sudah memenuhi syarat rumah sehat.

\section{DISKUSI}

\subsubsection{Pola Asuh Orang Tua}

Faktor lain yang juga memberi pengaruh pada peningkatan kasus ISPA yaitu pola asuh ibu yang baik akan membentuk perilaku yang juga baik terhadap anaknya begitu pula sebaliknya pola asuh ibu yang kurang akan mempengaruhi terhadap kebiasaan dan perilaku anaknya, sehingga dapat meningkatkan angka kesakitan anak dan anggota keluarga lain serta rentan dari penyakit, termasuk penyakit ISPA. Pengasuhan adalah suatu sikap dan praktek yang dijalankan oleh orang dewasa (ibu atau pengasuh lain) meliputi pemberian makanan berupa asupan energi dan protein kepada balita, mencegah dari kuman patogen dan serangan penyakit, pencegahan dan pengobatan saat balita ISPA. ${ }^{6}$

Hasil penelitian yang di dapatkan di wilayah kerja puskesmas Pasir Putih mengenai pola asuh orang tua bahwa informan tidak memperdulikan asupan makan yang di berikan kepada balita dikarenakan kesibukan orang tua sebagai petani, informan juga tidak mengetahui jenis makanan yang mengandung energi dan protein sehingga balitanya kurus dan lemas yang bisa berdampak pada status gizi balita yang kurang sehingga balita muda di serang penyakit khususnya ISPA, informan juga kurang memahami bagaimana agar balitanya terhindar dari kuman dan patogen penyebab penyakit di karenakan sibuk dengan aktivitasnya sehari-hari sebagai petani sehingga waktu dan tempat bermain balitanya tidak di kontrol dengan baik. Informan juga tidak mengetahui pencegahan dan pengobatan dini terhadap balitannya yang ISPA di karenakan kurang mendapatkan informasi dari petugas kesehatan dan juga jarak pelayanan kesehatan yang jauh dengan rumah informan, selain itu informan juga jarang membawa anaknnya ke posyandu karena sibuk dengan pekerjaannya. Ketika balitanya mengalami ISPA informan hanya mengandalkan dukung atau tukang urut, mengompres dengan air dingin dan membasahkan ubun-ubun atau kepada dengan air sebagai pengobatan dini pada saat balita ISPA.

Penelitian ini sejalan dengan penelitian yang dilakukan oleh ${ }^{7}$ Gambaran Pengetahuan dan Pola Asuh Ibu Pada Balita ISPA Di Puskesmas Bantarkalong Tasikmalaya di dapatkan bahwa pengetahuan dan polah asuh orang tua tidak tidak menjadi prioritas di karenakan kesibukan orang tua dan juga kurangnya pemahaman orang tua terhadap pola asuh balita yang baik.

Sehingga dapat disimpulkan pola asuh orang tua yang meliputi pemberian makanan berupa asupan energi dan protein, pencegahan dan pengobatan 
saat balita ISPA dapat merupakan salah sati faktor yang mempengaruhi kejadi ISPA pada balita di wilayah kerja Puskesmas Pasir Putih Kabupaten Muna.

\subsubsection{Lingkungan Rumah}

Pencemaran udara dalam rumah adalah terdapatnya udara yang tidak baik masuk kedalam rumah yang dapat mengganggu saluran pernapasan terutama pada anak-anak atau balita. Pencemaran udara dalam rumah dicontohkan seperti pembakaran sampah dari luar masuk ke dalam rumah, asap rokok yang berada dalam rumah, bahan bakar memasak dari kayu bakar hingga asapnya mencemari udara dalam rumah, dan pencemaran udara lainnya yang membuat saluran pernapasan terganggu. ${ }^{8}$

Hasil penelitian yang didapatkan di wilayah kerja Puskesmas Pasir Putih bahwa informan memiliki banyak sekali pencemaran udara yang ada di dalam rumah maupun lingkungan rumah. Pencemaran udara dan lingkungan ini di sebabkan kebiasaan mengolah sampah yang dilakukan dengan cara di bakar di pekarangan rumah, di mana ketika membakar sampah di pekarangan rumah asap yang di hasilkan dari pembakaran tersebut kalau di tiup angin mangarak di atas rumah selain itu informan membakar sampah ketika balita sedang bermain di pekarangan rumah ataupun masih sementara tidur di atas rumah yang terpapar oleh asap, bahan bakar memasak yang digunakan masih memaki kayu bakar, dan kondisi dapur yang tidak memiliki cerobong asap sehingga asap yang dihasilkan oleh kayu bakar tersebut mencemari udara di dalam rumah selain itu informan juga sering menggendong anaknya ketika memasak di dapur, serta paparan penghasil polutan seperti debu yang dihasilkan dari jalan raya yang terletak di depan rumah warga, di mana balita terpapar debu dikarenakan informan atau yang menjaga balita saat bermain di depan rumah itu tidak menutup hidungnya ketika ada debu.

Selain itu, kondisi listrik yang sering padam pada malam hari yang mengharuskan ibu rumah tangga menggunakan lampu tembok atau lampu minyak yang di gunakan sebagai alat penerang di mana lampu minyak tersebut menghasilkan asap sebagai salah satu penyebab lingkungan rumah tercemar. Pencemaran udara di dalam rumah juga di sebebkan oleh asap rokok, di mana masih terdapat anggota keluarga yang merokok di dalam rumah. Hal ini di anggap tidak menjadi masalah bagi ibu balita karena kurang mengetahui bahaya perokok pasif dan perokok aktif. Bahkan, di ruangan tamu terdapat asbak rokok yang memang di sediakan untuk tamu, karena hampir setiap tamu yang datang selalu merokok di dalam rumah.

Penelitian sebelumnya dilakukan oleh ${ }^{9}$ mengenai Faktor-Faktor Lingkungan Rumah yang Mempengaruhi kejadian ISPA pada Balita didapatkan bahwa jenis bahan bakar yang digunakan mempengaruhi kejadian ISPA dimana jenis bahan bakar yang di pakai masih menggunakan kayu bakar. Selain itu pencemaran udara juga di sebabkan karena adanya aktifitas anggota keluarga seperti merokok dalam rumah dan ada lingkungan sekitar terdapat tempat pembakaran sampah yang asapnya masuk ke dalam rumah sehingga lingkungan rumah tercemar.

Sehingga dapat disimpulkan lingkungan rumah informan yang meliputi pengolahan sampah, bahan bakar memasak dan paparan penghasil polutan merupakan salah satu faktor yang mempengaruhi kejadian ISPA pada balita di wilayah kerja Puskesmas Pasir Putih Kabupaten Muna.

\subsubsection{Kondisi Fisik Rumah}

Kepadatan penghuni didalam rumah merupakan salah satu faktor terjadinya penyakit ISPA karena dengan tempat yang sempit dengan penghuni yang banyak dapat meningkatkan faktor polusi udara dalam rumah, selain itu juga dapat menghalangi proses pertukaran udara bersih di dalam rumah ${ }^{10}$. Luas rumah yang dikatakan rumah sehat dan tidak padat yakni berkisar $36 \mathrm{~m} 2$ atau diukur dengan $9 \mathrm{~m} 2$ perjiwa $^{11}$. Keputusan Menteri Kesehatan No. 829/Menkes/SK/VII/2008 juga menyatakan bahwa luas ruang tidur minimal $8 \mathrm{~m} 2$ dan tidak dianjurkan digunakan lebih dari 2 (dua) orang tidur dalam satu ruang tidur, kecuali anak di bawah umur 5 tahun.

Hasil penelitian yang dilakukan untuk luas rumah dalam pengukuran kepadatan hunian yaitu semua rumah informan mempunyai luas lantai lebih dari 8 meter per jiwa, dan juga untuk 1 ruang tidur di huni 2 orang dewasa, hal ini juga di karenakan sebagian informan sudah memiliki rumah sendiri-sendiri yang sudah tidak tinggal bersama orang tua atau keluarga sehingga yang tinggal di dalam rumah hanya balita dan anak-anak yang sudah dewasa. Selain itu pembuatan rumah dengan ukuran kamar lebih dari 8 m2 perjiwa hanya secara kebetulan saja, bukan berdasarkan pengetahuan syarat rumah sehat.

Penelitian sebelumnya yang dilakukan oleh ${ }^{12}$ bahwa terdapat beberapa rumah yang kepadatan huniannya sudah memenuhi syarat kesehatan yaitu lebih dari $8 \mathrm{~m} 2$ perjiwa sehingga balita tidak mengalami ISPA berat, balita yang mempunyai kepadatan hunian rumah lebih dari $8 \mathrm{~m} 2$ perjiwa hanya mengalami ISPA ringan yang di sebabkan oleh faktor lain. 
Ventilasi merupakan tempat daur ulang udara yaitu tempatnya udara masuk dan keluar. Ventilasi yang dibutuhkan untuk penghawaan di dalam rumah yakni ventilasi memiliki luas minimal $10 \%$ dari luas lantai rumah ${ }^{13}$.

Hasil penelitian untuk ventilasi dari 3 orang informan hanya 1 (satu) rumah yang mempunyai ventilasi rumah kurang dari $10 \%$ dari luas lantai rumah sedangkan sisanya sama sekali tidak mempunyai ventilasi di dalam rumah, hanya ada pintu dan jendela sebagai tempat keluar masuknya angin. Hal ini dikarenakan informan tidak menghiraukan besar ventilasi tapi lebih memperdulikan bagaimana mereka cukup untuk tidur dan tempat pertukaran udara mereka lebih sering menggunakan pintu yakni dengan cara pintu rumah sering dibuka lebar. Selain itu karena keterbatasan kondisi ekonomi dan penghasilan yang belum memadai sehingga mereka belum bisa membuat ventilasi rumah yang memenuhi syarat kesehatan.

Penelitian sebelumnya yang dilakukan oleh ${ }^{14}$ berdasarkan hasil wawancara dan observasi masih terdapat banyak rumah balita ISPA yang tidak memiliki ventilasi sebagai tempat keluar masuknya angin yang dikarenakan kurangnya pemahaman mengenai fungsi ventilasi itu sendiri dan tidak mementingkan keberadaan verntilasi tersebut.

Syarat rumah yang sehat lantai yang tidak berdebu pada musim kemarau dan tidak basah pada musim penghujan. Lantai rumah dapat terdiri dari ubin atau semen, kayu dan tanah yang disiram kemudian dipadatkan. Lantai yang basah dan berdebu dapat menimbulkan sarang penyakit. Bahan lantai harus kedap air dan mudah dibersihkan, paling tidak perlu di plester dan akan lebih baik kalau dilapisi ubin atau keramik yang mudah dibersihkan ${ }^{15}$.

Hasil penelitian yang dilakukan di wilayah kerja Puskesmas Pasir Putih jenis lantai belum memenuhi syarat rumah sehat dimana masih terdapat rumah dengan jenis lantai berbahan dasar semen dan tanah. Hal ini dikarenakan kondisi ekonomi dan penghasilan yang rendah di mana mereka hanya bekerja sebagai petani sehingga tidak dapat membuat lantai yang berbahan dasar ubin atau keramik.

Hasil penelitian ${ }^{12}$ menunjukan bahwa lantai rumah rata-rata di Desa Tual memakai jenis lantai semen dan tanah. Balita yang terkena ISPA mempunyai lantai rumah yang tidak memenuhi syarat hal ini disebabkan karena lantai rumah responden rata-rata berupa lantai semen dan tanah, sehingga pada musim kemarau akan menghasilkan debu. Lantai yang terbuat dari semen dan dan rata- rata sudah rusak dan tidak kedap air, sehingga lantai menjadi berdebu dan lembab.

Sehingga dapat disimpulkan bahwa kondisi fisik rumah yang meliputi luas ventilasi, jenis lantai yang belum memenuhi syarat merupakan salah satu faktor yang mempengaruhi kejadian ISPA di wilayah kerja Puskesmas Pasir Putih Kabupaten Muna.

\section{SIMPULAN}

1. Pola asuh orang tua yang meliputi pola asuh dalam pemberian makanan kepada balita, pola asuh dalam upaya pencegahan penyakit dan pengobatan saat balita ISPA, dimana kesibukan dari ibu balita terhadap pekerjaannya dan ketidakpedulian kepada balita serta kurangnya pemahaman mengenai pola asuh yang baik terhadap balita, sehingga pola asuh orang tua menjadi salah satu faktor penyebab balita ISPA.

2. Lingkungan rumah dimana terdapat pencemran udara di dalam rumah dikarenakan pengolahan sampah dengan cara di bakar di pekarangan rumah yang mengasilkan asap yang langsung di atas rumah, bahan bakar yang digunakan masih menggunakan kayu dan dapur yang tidak memiliki cerobong asap sehingga asap menyebar di dalam rumah selian itu ibu balita memasak sambil menggendong balitanya, polutan dan debu dari jalan raya yang terletak di depan rumah, penggunaan lampu minyak yang mengasilkan asap serta perilaku merokok anggota keluarga ataupun tamu yang menjadi salah satu faktor penyebab balita ISPA.

3. Kondisi fisik rumah seperti kepadatan hunian rumah, ventilasi rumah dan jenis lantai rumah yang tidak memenuhi syarat rumah sehat di karenakan ketidak pedulian informan dan kurangnya pemahaman tentang kondisi fisik rumah yang memenuhi syarat serta kurangnya penghasilan dikarenakan kondisi ekonomi yang di kategorikan rendah dan pekerjaan yang tidak memadai sehingga kondisi fisik rumah yang tidak memenuhi syarat kesehatan dapat menyebabkan terjadinya ISPA pada balita.

\section{SARAN}

1.

lagi pola asuh pada balitanya yang meliputi pola asuh dalam pemberian makanan kepada balita, pola asuh dalam upaya pencegahan penyakit dan pengobatan saat balita ISPA, lebih meningkatkan lagi keperduliannya terhadap balita agar balita tidak terkena ISPA.

2. Lebih memperhatikan lagi lingkungan di sekitar rumah seperti 
menghilangkan kebiasaan mengolah sampah dengan cara di bakar, membuat cerbong asap di dapur dan tidak memasak sambil menggendong balitanya agar balita tidak terpapar oleh asap yang di hasilkan dari kayu bakar, menutup hidung balita saat ada debu dan tidak membiarkan anggota keluarga ataupun tamu yang merokok di dalam rumah.

Lebih memperhatikan lagi kondisi fisik rumah seperti luas ventilasi rumah harus memenuhi syarat rumah sehat, dan jenis lantai rumah dibuat berdasarkan sayar rumah sehat.

\section{DAFTAR PUSTAKA}

1. WHO. 2017. Mental Disorders Fact Sheets. Jenewa: World Health Organization

2. Krishnan et al. 2015. Epidemiology of Acute Respiratory Infections In Children-Preliminary Result of A Cohort In A Rular North Indian Comuniti. BioMed Central Infection Disease, 15.462

3. Kemenkes RI. 2016. Pedoman Program P2 ISPA Untuk Penanggulangan Pneumonia Pada Balita. Jakarta: Kemenkes RI

4. Kemenkes RI. 2018. Data dan Informasi Profil Kesehatan Indonesia 2017. Jakarta: Kemenkes RI

5. Soetjiningsih. 2012. Perkembangan Anak dan Permasalahannya Dalam Buku Ajar II IImu Perkembangan Anak dan Remaja. Jakarta: EGC

6. Wirandoko, Ignatius Hapsoro. 2017. Gambaran Pengetahuan dan Pola Asuh Ibu Pada Balita ISPA di Puskesmas Bantarkalog Tasikmalaya . Tasikmalaya: Bina Pustak

7. WHO. 2013. Indikator Perbaikan Kesehatan Lingkungan Anak. Jakarta: EGC

8. Yuwono. 2012. Faktor-faktor Lingkungan Rumah Yang Berhubungan Dengan Kejadian ISPA Pada Balita Di Wilayah Kerja Puskesmas Kawunganten Kabupaten Cilacap. Tesis S2 Megister Kesehatan Lingkungan Unviversitas Diponegoro Semarang.

9. Sukandarrumidi. 2010. Metode Bencana Alam dan Bencana Anthropagene. Yogyakarta: Kanisus

10. Kemenkes RI. 2018. Data dan Informasi Profil Kesehatan Indonesia 2017. Jakarta: Kemenkes RI

11. Sadono, 2012. Bayi Berat Lahir Rendah Sebagai Salah Satu Faktor Resiko ISPA Pada Bayi di Kabupaten Blora. Jurnal yang didapatkan pada www.pdffactory.com

12. Notoatmodjo S. 2010. Metodologi Penelitan Kesehatan. Jakarta: Rineka Cipta 
Jurnal Ilmiah Mahasiswa Kesehatan Masyarakat Vol.5 No.2 April 2020 ; Issn 2502-731X 
